\title{
Wind Turbine Electrical Energy Supply System for Oil Well Heating
}

\author{
A. A. Belsky ${ }^{1)}$, V. A. Morenov' ${ }^{1)}$, K. S. Kupavykh ${ }^{1)}$, M. S. Sandyga ${ }^{1)}$ \\ ${ }^{1)}$ Saint-Petersburg Mining University (Saint-Petersburg, Russian Federation) \\ (C) Белорусский национальный технический университет, 2019 \\ Belarusian National Technical University, 2019
}

\begin{abstract}
In this article, the authors reviewed a new technology to prevent the formation of asphalt-resin-paraffin deposits by the thermal method of electrothermal impact on the oil wellbore shaft using a wind-electric installation as an autonomous power source. The advantage of this thermal stimulation technique lies in its continuous nature, which will allow keeping the clear opening of the tubing constant. The scheme of the autonomous system for down-hole electric heating of oil is presented. A tubular or induction heater can serve as an electric heating element placed in the well. The heating element of the system can be used in the wells exploited by freeflow, gas lift and mechanized methods, while its installation does not require an overhaul. The paraffin oil saturation temperature and temperature distribution over the depth of the well were defined. The amount of heat, which must be transferred to the oil mixture in the tubing in order to ensure effective operation of the well, taking into account the dynamic state of the system, is calculated. The optimal depth of the heating element's location in the well and its power was determined. The calculation of the required power for wind-electric installation to maintain the set temperature in the wellbore was performed. Having conducted the studies, it was revealed that in order to prevent the asphalt-resin-paraffin deposits formation on the tubing walls of oil wells, it is expedient to use the in-line heater, which maintains the average steady-state temperature along the wellbore and at the wellhead above the initial crystallization point of the asphaltresin-paraffin deposits. The application of the developed electrothermal system is relevant in the conditions of formation of asphalt-resin-paraffin deposits in the wellbore shaft at the fields, which do not have a connection to the centralized power grid.
\end{abstract}

Keywords: asphalt-resin-paraffin deposits, oil well, wind-electric installation, tubing, electrothermal impact, thermal method

For citation: Belsky A. A., Morenov V. A., Kupavykh K. S., Sandyga M. S. (2019) Wind Turbine Electrical Energy Supply System for Oil Well Heating. Energetika. Proc. CIS Higher Educ. Inst. and Power Eng. Assoc. 62 (2) 146-154. https://doi.org/10.21122/1029-7448-2019-62-2-146-154

\section{Электроснабжение станции нагрева нефти в скважине от ветроэлектрической установки}

\author{
А. А. Бельский(), В. А. Моренов ${ }^{1)}$, К. С. Купавых ${ }^{1)}$, М. С. Сандыга ${ }^{1)}$ \\ ${ }^{1)}$ Санкт-Петербургский горный университет (Санкт-Петербург, Российская Федерация)
}

Реферат. Рассмотрена новая технология предупреждения образования асфальтосмолопарафиновых отложений тепловым методом электротермического воздействия на ствол нефтя-

\author{
Адрес для переписки \\ Моренов Валентин Анатольевич \\ Санкт-Петербургский горный университет \\ Васильевский остров 21 линия, д. 2, \\ 199106, г. Санкт-Петербург, \\ Российская Федерация \\ Тел.: +7 812 328-82-20 \\ morenov@spmi.ru
}

\author{
Address for correspondence \\ Morenov Valentin A. \\ Saint-Petersburg Mining University \\ 2 Vasilievsky island $21^{\text {st }}$ Line \\ 199106, Saint-Petersburg, \\ Russian Federation \\ Tel.: +7 812 328-82-20 \\ morenov@spmi.ru
}


ной скважины с применением ветроэлектрической установки в качестве автономного источника питания. Достоинством данного теплового способа воздействия является его непрерывный характер, что позволяет сохранять пропускное сечение насосно-компрессорных труб постоянным. Представлена схема автономного комплекса для внутрискважинного электропрогрева нефти. В качестве электронагревательного элемента, размещаемого в скважине, может выступать трубчатый или индукционный нагреватель. Нагревательный элемент комплекса может применяться в скважинах, эксплуатируемых фонтанным, газлифтным и механизированным способами, при этом для его установки не требуется проведения капитального ремонта. Определены температура насыщения нефти парафином и ее распределение по глубине скважины. Рассчитано количество теплоты, которое необходимо сообщить скважинной продукции в насосно-компрессорных трубах для обеспечения эффективного режима эксплуатации скважины с учетом динамического состояния системы. Установлены оптимальная глубина расположения нагревательного элемента в скважине и его мощность. Выполнен расчет необходимой мощности ветроэлектрической установки для поддержания заданной температуры в стволе скважины. Проведенные исследования показали, что для предотвращения образования асфальтосмолопарафиновых отложений на стенках насосно-компрессорных труб нефтяных скважин целесообразно использовать проточный электронагреватель, который обеспечивает поддержание средней установившейся температуры по стволу и на устье скважины выше точки начальной кристаллизации асфальтосмолопарафиновых отложений. Применение разработанного электротермического комплекса является актуальным в условиях образования асфальтосмолопарафиновых отложений в стволе скважины на месторождениях, не имеющих подключения к централизованной энергосистеме установки для поддержания заданной температуры в стволе скважины.

Ключевые слова: асфальтосмолопарафиновые отложения, нефтяная скважина, ветроэлектрическая установка, насосно-компрессорная труба, электротермическое воздействие, тепловой метод

Для цитирования: Электроснабжение станции нагрева нефти в скважине от ветроэлектрической установки / А. А. Бельский [и др.] // Энергетика. Изв. высш. учеб. заведений и энерг. объединений СНГ. 2019. Т. 62, № 2. С. 146-154. https://doi.org/10.21122/1029-7448-2019-62-2146-154

\section{Introduction}

Intra-field communications represent a single hydrodynamic network, which operation complexity is associated with constant thermobaric variations and phase conversions. One of the key problems of oil production is the formation of organic deposits on any of the technological levels of this system [1, 2]. The choice of methods to influence wells, their bottom-hole zone and the entire formation, optimization of the existing and developing new approaches to control deposits are the tasks of urgency, the solution of which will improve the technological efficiency and economic stability of oil production enterprises and the industry as a whole.

Paraffin deposits in wells and in the bottom-hole formation zone are the subject of a primary consideration in oil production industry.

The asphalt-resin-paraffin deposits (ARPD), accumulating on the surfaces of the tubing, as well as in the pumping equipment and in the bottom-hole formation zone, result in a reduction in the overhaul period and in a decrease in the well performance efficiency $[3,4]$.

Currently, all methods of controlling deposits are divided into two main groups: methods of removing already formed deposits and methods of preven- 
ting their formation. Due to a great variety of conditions for the development of oil fields, various technological parameters and geological and physical conditions, as well as fluid properties, it is expedient to use an individual comprehensive approach to the selection of technologies.

Fig. 1 presents classification according to which the following techniques of controlling the asphalt-resin-paraffin deposits are specified: chemical, physical, thermal, mechanical, smooth pipe coatings and integral action (applying several methods) $[1,5,6]$.

The most efficient methods of controlling paraffin deposits are thermal methods of affecting the wellbore, based on the ability of the ARPD not to form a solid phase or melt at temperatures higher than the crystallization temperature of $35-50{ }^{\circ} \mathrm{C}[4,6-9]$.

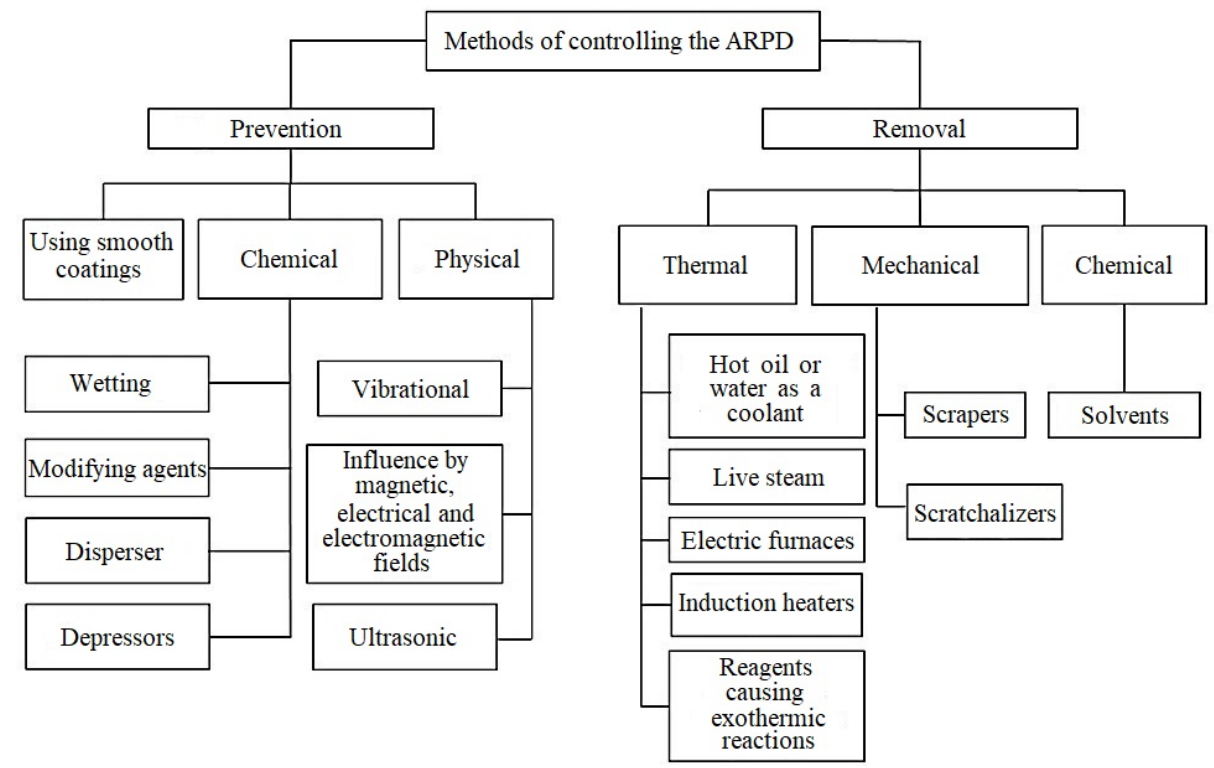

Fig. 1. Classification of methods of controlling the ARPD [5]

The article deals with the electro-thermal impact on the ARPD on the tubing walls in the well. The advantage of this thermal stimulation technique lies in its continuous nature, which will allow keeping the clear opening of the tubing constant. A tubular or induction heater can serve as an electric heating element placed in the well $[10,11]$. The disadvantage of electric heating lies in its dependence on the presence and reliability of an external power supply system. Most present-day oil fields in Russia are located within remote areas, far from the centralized power supply system. The use of autonomous power supply systems on the basis of wind-driven power plants may be considered as an alternative to the reconstruction of old or construction of new electrical networks [12-14].

The aim of this work is to determine the required power of the wind-driven power plant to ensure the efficiency of the down-hole heating element operation to prevent the ARPD formation. 


\section{Scheme of the system}

Electric heating is carried out using a heating element, placed directly in the inner space of the tubing in the well, which allows heating any types of wells when implementing free-flow, gas-lift and electromechanical methods of oil production [15]. Such a scheme for implementation of electric heating does not require underground work, and in some cases it does not need well shutdown [16]. The process of lowering the heating element is carried out using a load-carrying cable and complies with standard work with geophysical instruments. The tubular or induction electric heating element is in contact with downhole fluid, so the heat transfer goes directly into the fluid [17].

The structure of the autonomous system for down-hole electric heating of oil comprises (fig. 2): 1 - wind-driven power plant; 2 - feeding cable; 3 -oil heating unit control station; 4-power cable; 5-temperature sensor cable; 6 -terminal cabinet; 7 -safety lock; 8 -load-carrying cable; 9 -thermowell temperature sensor cable; 10 - lubricating device; 11 -tmain lock; 12 -wellhead equipment; 13 -thermowell with temperature sensor; 14 -receiving pipeline; 15 - tubing; 16 - casing string; 17 - electric heater.

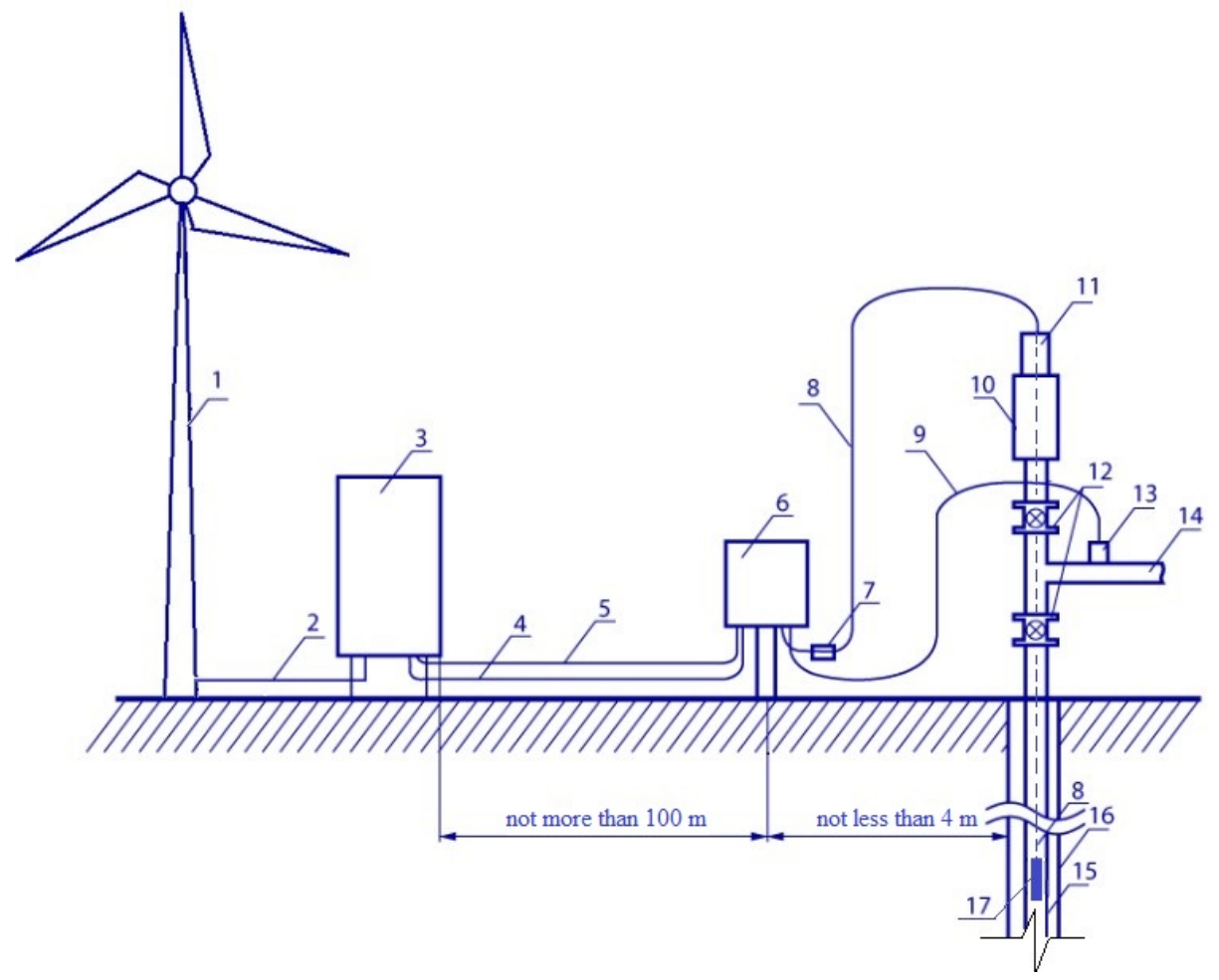

Fig. 2. Schematic view of an autonomous system for down-hole electric heating of oil

\section{Calculating the depth of lowering the heating element}

As a source data for lowering the heating cable, the well of one of the fields in Western Siberia was selected. The selected well parameters are presented in tab. 1. 
Parameters of the well

Table 1

\begin{tabular}{|l|c|c|}
\hline Well production rate for liquid under standard conditions $\left(\mathrm{m}^{3} /\right.$ day) & $Q_{V}$ & 35 \\
\hline Well depth $(\mathrm{m})$ & $L$ & 2900 \\
\hline Gas to oil ratio $\left(\mathrm{m}^{3} / \mathrm{m}^{3}\right)$ & $G$ & 29.2 \\
\hline Average value of the well angle of slope $($ deg. $)$ & $\alpha$ & 9 \\
\hline Formation pressure $(\mathrm{MPa})$ & $P$ & 27 \\
\hline Production string inner diameter $(\mathrm{m})$ & $D$ & 0.15 \\
\hline Formation oil density $\left(\mathrm{kg} / \mathrm{m}^{3}\right)$ & $\rho_{\text {oil }}$ & 748.3 \\
\hline Oil specific heat $(\mathrm{J} /(\mathrm{kg} \cdot \mathrm{K}))$ & $c_{o i l}$ & 880 \\
\hline Coefficient of water cut & $b$ & 0.75 \\
\hline Formation water density $\left(\mathrm{kg} / \mathrm{m}^{3}\right)$ & $\rho_{w}$ & 1050 \\
\hline Formation water specific heat $(\mathrm{J} /(\mathrm{kg} \cdot \mathrm{K}))$ & $c_{w}$ & 4100 \\
\hline Formation temperature $(\mathrm{K})$ & $T_{l}$ & 364 \\
\hline Inner diameter of the tubing $(\mathrm{m})$ & $d$ & 0.0503 \\
\hline
\end{tabular}

The composition of the ARPD selected from the wellhead (selection date: December $\left.10^{\text {th }}, 2005\right)$ is as follows: asphaltenes $-2.45 \%$, resins $-12.5 \%$, paraffins $-4.4 \%$. The melting temperature of paraffin, extracted from degassed oil under laboratory conditions, is $62-70{ }^{\circ} \mathrm{C}$.

\section{Determining the paraffin saturation point for oil}

When determining the paraffin saturation point for oil, the formula, recommended by All-Russia Institute for Oil and Gas Research ("VNIIneft"), is used [3]:

$$
\begin{gathered}
t=t_{0}+0.2 P-0.1 G=33.33+0.2 \cdot 27-0.1 \cdot 29.2=35.81{ }^{\circ} \mathrm{C}=308.81 \mathrm{~K} ; \\
t_{0}=11.398+34.084 \lg C_{p}=11.398+34.084 \lg 4.4=33.33{ }^{\circ} \mathrm{C},
\end{gathered}
$$

where $t$ - paraffin saturation point under the formation conditions, $\mathrm{K} ; t_{0}$ - paraffin saturation point under the surface conditions, ${ }^{\circ} \mathrm{C} ; P$ - formation pressure, MPa; $G$ - gas to oil ratio, $\mathrm{m}^{3} / \mathrm{m}^{3} ; C_{p}$ - paraffin concentration in oil, $\%$.

Mass paraffin precipitation begins in the well at a depth corresponding to the temperature of paraffins crystallization initial point. Within the subsequent interval, massive formation of paraffins takes place, and closer to the wellhead and in the onshore pipelines, deposits in the form of resins occur $[18,19]$.

\section{Temperature distribution over the well depth}

The temperature distribution along the depth of the well can be presented by the formula [3]

$$
T(H)=T_{l}-(L-H) \cdot \frac{0.0034+0.79 \omega \cos \alpha}{10^{Q_{V} /\left(86400 \cdot 20 d^{2.67}\right)}},
$$

where $T_{l}$ - formation temperature, $\mathrm{K} ; L$ - well depth, $\mathrm{m} ; H$ - current depth, measured from the wellhead, $\mathrm{m} ; \alpha$ - well angle of inclination from the vertical, deg.; $Q_{V}$ - well production rate for liquid under standard conditions, $\mathrm{m}^{3} /$ day; $d$-inner diameter of the tubing, $\mathrm{m}$; $\omega$ - geothermal gradient, deg./m, calculated using the formula 


$$
\omega=\frac{T_{l}-T_{n}}{\left(L-H_{n}\right) \cos \alpha}=\frac{364-278}{(2900-20) \cos 9^{\circ}}=0.03023,
$$

where $T_{n}$ - neutral layer temperature, $\mathrm{K} ; H_{n}$ - neutral layer depth, m.

The temperature of the neutral layer for the oil area of Western Siberia is set as $T_{n}=278 \mathrm{~K}$. The depth of the neutral layer below the earth's surface varies from 20 to $40 \mathrm{~m}$, in this paper let us set it as $H_{n}=20 \mathrm{~m}$.

Example of calculating the down-hole temperature at a depth of $100 \mathrm{~m}$

$$
T(H)=364-(2900-100) \cdot \frac{0.0034+0.79 \cdot 0.03023 \cdot \cos 9^{\circ}}{10^{\frac{35}{\left(86400 \cdot 20 \cdot 0.0503^{2.67}\right)}}}=298.1 \mathrm{~K} .
$$

The results of calculating the temperature distribution over the well depth from 0 to $1500 \mathrm{~m}$ are presented in fig. 3. Thus, it may be concluded that the

\begin{tabular}{|c|c|c|}
\hline Depth, $m$ & Temperature, $\mathrm{K}$ & \multirow[b]{7}{*}{ The paraffin saturation point for oil } \\
\hline 0 & 295.7 & \\
\hline 100 & 298.1 & \\
\hline 200 & 300.4 & \\
\hline 300 & 302.8 & \\
\hline 400 & 305.1 & \\
\hline 500 & 307.5 & \\
\hline 600 & 309.9 & \multirow[t]{10}{*}{ The depth of lowering the heating element } \\
\hline 700 & 312.2 & \\
\hline 800 & 314.6 & \\
\hline 900 & 316.9 & \\
\hline 1000 & 319.3 & \\
\hline 1100 & 321.6 & \\
\hline 1200 & 324.0 & \\
\hline 1300 & 326.3 & \\
\hline 1400 & 328.7 & \\
\hline 1500 & 331.0 & \\
\hline
\end{tabular}
heating element must be lowered to a depth of $600 \mathrm{~m}$.

Fig. 3. Temperature distribution along the depth of the well

\section{Heat calculation}

Let us determine the amount of heat, required for in-line heating of the water-oil mixture in a well with a specified production rate using the formula

$$
Q=c_{m i x} m \Delta T,
$$

where $Q$ - amount of heat, received by the substance during heating, $\mathrm{J} ; c_{m i x}-$ specific heat of the water-oil mixture, $\mathrm{J} /(\mathrm{kg} \cdot \mathrm{K}) ; m$ - mass of the heated wateroil mixture, $\mathrm{kg} ; \Delta T$ - difference between the final and initial temperatures of the substance, $\mathrm{K}$.

The specific heat of the water-oil mixture is determined by

$$
c_{\text {mix }}=c_{\text {oil }}(1-b)+c_{w} b=880 \cdot(1-0.75)+4100 \cdot 0.75=3295 \mathrm{~J} /(\mathrm{kg} \cdot \mathrm{K}),
$$

where $c_{\text {oil }}$ - specific heat of oil, $\mathrm{J} /(\mathrm{kg} \cdot \mathrm{K}) ; c_{w}-$ specific heat of formation water, $\mathrm{J} /(\mathrm{kg} \cdot \mathrm{K}) ; \mathrm{b}$ - coefficient of water cut. 
The mass of the heated water-oil mixture in the tubing is determined by

$$
m=V \rho_{\text {mix }},
$$

where $V=Q_{V} / 24$ - volume of the water-oil mixture, passing through the heating element per 1 hour, $\mathrm{m}^{3} ; \rho_{\text {mix }}$ - density of the water-oil mixture, $\mathrm{kg} / \mathrm{m}^{3}$.

The density of the water-oil mixture in the tubing is determined by

$$
\rho_{\text {mix }}=\rho_{\text {oil }}(1-b)+\rho_{w} b=748.3 \cdot(1-0.75)+1060 \cdot 0.75=982.1 \mathrm{~kg} / \mathrm{m}^{3},
$$

where $\rho_{o i l}-$ density of formation oil, $\mathrm{kg} / \mathrm{m}^{3} ; \rho_{w}$ - density of formation water, $\mathrm{kg} / \mathrm{m}^{3}$.

Using the in-line electric heating element, it is necessary to heat the water-oil mixture at a depth of $600 \mathrm{~m}$ in such a manner that the introduced amount of heat is sufficient to compensate for the temperature drop below the paraffin saturation point further along the wellbore towards the wellhead.

As a result of previous calculations, it was found that the initial temperature of paraffins crystallization is $308.8 \mathrm{~K}$, and the temperature at the wellhead is $295.7 \mathrm{~K}$. Thus, it is necessary to calculate the amount of heat required for heating the water-oil mixture by $13.1 \mathrm{~K}$ within an hour using the down-hole in-line heater.

While calculating, it was assumed that the well production rate is constant and does not change upwards due to a decrease in the viscosity of oil during heating or downwards resulting from a decrease in the clear opening of the tubing, as well as thermal losses

The heated volume of the water-oil mixture in the tubing is equal to

$$
V=\frac{Q_{V}}{24}=\frac{35}{24}=1.4583 \mathrm{~m}^{3} .
$$

The heated mass of the water-oil mixture in the tubing is equal to

$$
m=V \rho_{\text {mix }}=1.4583 \cdot 982.1=1432.20 \mathrm{~kg} .
$$

The amount of heat required for heating the water-oil mixture in the tubing is equal to

$$
Q=c_{m i x} m \Delta T=3295 \cdot 1432.20 \cdot 13.1=61820196.9 \mathrm{~J}=17.17 \mathrm{~kW} \cdot \mathrm{h} .
$$

The inner diameter of the production string is $0.15 \mathrm{~m}$, and the outer diameter of the tubing string is $0.0603 \mathrm{~m}$. Thus, the casing annulus of the well is represented by $0.0449 \mathrm{~m}$ thick water-oil mixture ring. The ratio between the outer diameter of the tubing string and the inner diameter of the casing string is $2 / 5$. Regarding this, we take the energy losses during heating the liquid column equal to $40 \%$ of the previously calculated amount of heat, in this case equal to $Q_{\text {loss }}=6.87 \mathrm{~kW} \cdot \mathrm{h}$.

Thus, to prevent the ARPD formation on the tubing walls in the oil wellbore under specified conditions, it is necessary to use the in-line electric heater with a power of $P=24.04 \mathrm{~kW}$. 


\section{Selecting a wind-driven power plant}

According to the study, presented in [20], the installed capacity utilization factor (ICUF) of a wind-driven power plant as part of an electro-thermal system depends on the average annual wind speed; variations in ranking of wind distribution, the heating cable resistance and the method of controlling. Minimum values of the ICUF of a wind-driven power plant as a part of the system, depending on the average annual wind speeds, are presented in tab. 2 .

Table 2

ICUF of the wind-driven power plant as a part of an electro-thermal complex

\begin{tabular}{|l|c|c|c|c|}
\hline Average annual wind speed, $\mathrm{m} / \mathrm{s}$ & 4 & 5 & 6 & 7 \\
\hline Minimum ICUF, \% & 10 & 16.3 & 22.8 & 27.1 \\
\hline
\end{tabular}

Let us determine the power of the wind-driven power plant as a part of an electro-thermal system with the in-line electric heater to remove and prevent the ARPD formation on the tubing walls in the oil wellbore based upon minimum ICUF (tab. 2) and the time to reach the set temperature at the wellhead $(T=308.8 \mathrm{~K})$ within an hour using the formula

$$
P_{W G}=\frac{P}{k} \cdot 100,
$$

where $P_{W G}-$ power of the wind-driven power plant, $\mathrm{kW} ; P$ - power of the inline electric heater, $\mathrm{kW} ; k$ - minimum ICUF of the wind-driven power plant, $\%$.

Fig. 4 shows the influence of selecting a nominal capacity of the wind-driven power plant on the steady-state temperature at the wellhead, with variations in the average annual wind speed accounted for.

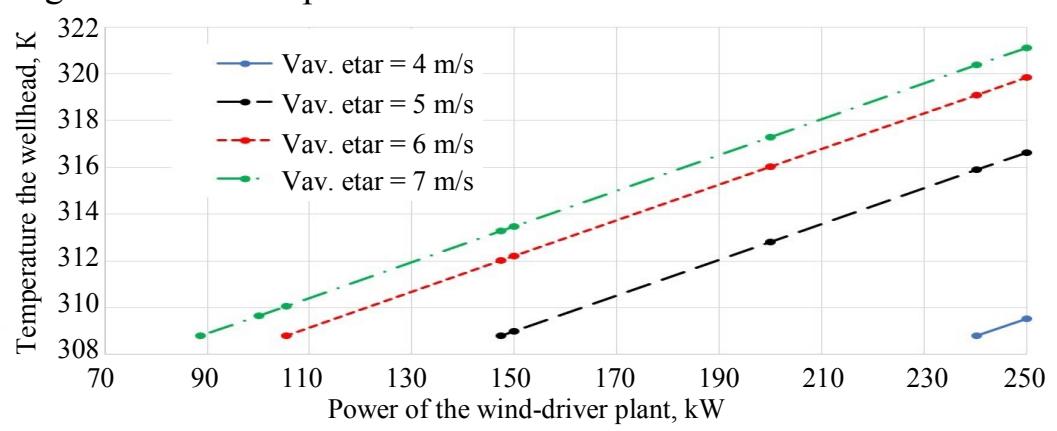

Fig. 4. Selecting a nominal capacity of the wind-driven power plant

\section{CONCLUSION}

Having conducted the studies, it was revealed that in order to prevent the ARPD formation on the tubing walls of oil wells, it is expedient to use the in-line heater, which maintains the average steady-state temperature along the wellbore and at the wellhead above the initial crystallization point of the ARPD. It is possible to use an autonomous wind-driven power plant with a nominal capacity of 90 to $250 \mathrm{~kW}$, depending on the average annual wind speed within the well pad area, as a power source for the electric heater.

The reported study was funded by RFBR according to the research project No 18-38-00530. 


\section{REFERENCES}

1. Ibragimov N. G., Tronov V. P., Guskova I. A. (2010) Theory and Practice of Methods for Controlling Organic Deposits at a Late Stage of the Development of Oil Deposits. Moscow. Neftyanoe Khozyaistvo Publ. 240 (in Russian).

2. Korobov G. Y., Mordvinov V. A. (2017) Study of Adsorption and Desorption of Asphaltene Sediments Inhibitor in the Bottomhole Formation Zone. International Journal of Applied Engineering Research, 12 (2), 267-272.

3. Korobov G. Y., Mordvinov V. A. (2013) Temperature Distribution Along Well Bore. Neftyanoe Khozyaistvo = Oil Industry, (4), 57-59 (in Russian).

4. Morenov V., Leusheva E. (2016) Energy Delivery at Oil and Gas Wells Construction in Regions with Harsh Climate. International Journal of Engineering, 29 (2), 274-279. https://doi.org/10.5829/idosi.ije.2016.29.02b.17.

5. Ivanova L. V., Koshelev V. N., Burov E. A. Asphaltene-Resin-Paraffin Deposits During Production, Transportation and Storage. Neftegazovoe Delo = Oil and Gas Business, 2011, (1), 274-276 (in Russian).

6. Glushchenko V. N., Silin M. A., Gerin Yu. G. (2009) Oil-Field Chemistry. Vol. 5. Prevention and Elimination of AsphalteneResin-Paraffin Deposits. Moscow, Interkontakt Nauka Publ. 475 (in Russian).

7. Ragulin V. V., Ganiev I. M., Voloshin A. I., Latypov O. A. (2003) Development of the Technology of Asphaltene-Resins-Paraffin Sediments Removal from Oil Field Equipment Surface. Neftyanoe Khozyaistvo = Oil Industry (11), 89-91 (in Russian).

8. Struchkov I. A., Rogachev M. K. (2017) Wax Precipitation in Multicomponent Hydrocarbon System. Journal of Petroleum Exploration and Production Technology, (7), 543-553. https://doi.org/10.1007/s13202-016-0276-0.

9. Struchkov I. A., Roschin P. V. (2016) Effect of Light Hydrocarbons on Wax Precipitation. International Journal of Applied Engineering Research, (11), 9058-9062.

10. Kopteva A. V., Malarev V. I. (2018) Studying Thermal Dynamic Processes in an Isolated Type Borehole Electrode Heater for High-Viscosity Oil Extraction. 2018 IEEE Conference of Russian Young Researchers in Electrical and Electronic Engineering (EIConRus), 678-681. https://doi.org/10.1109/EIConRus.2018.8317185.

11. Kopteva A. V., Malarev V. I. (2017) Borehole Electric Steam Generator Electro-Thermal Calculation for High-Viscosity Oil Productive Layers Development. 2017 International Conference on Industrial Engineering, Applications and Manufacturing (ICIEAM), 1-4. https://doi.org/10.1109/ICIEAM.2017.8076341.

12. Abramovich B. N., Sychev Yu. A. (2016) Problems of Ensuring Energy Security for Enterprises from Mineral Resources Sector. Zapiski Gornogo instituta = Journal of Mining Institute, 217, 132-139 (in Russian).

13. Gukovskiy Y. L., Sychev Y. A., Pelenev D. N. (2017) The Automatic Correction of Selective Action of Relay Protection System against Single Phase Earth Faults in Electrical Networks of Mining Enterprises. International Journal of Applied Engineering Research, 5 (12), 833-838.

14. Belsky A. A., Korolyov I. A. (2018) Thermal Oil Recovery Method Using Self-Contained Windelectric Sets. Journal of Physics: Conference Series, 1015, 052001. https://doi.org/10. 1088/1742-6596/1015/5/052001.

15. Belsky A. A., Dobush V. S. (2017) Autonomous Electrothermal Facility for Oil Recovery Intensification Fed by Wind Driven Power Unit. IOP Conference Series: Earth and Environmental Science, 87, 032006. https://doi.org/10.1088/1755-1315/87/3/032006.

16. Zyrin V. (2018) Electrothermal Complex for Heavy Oil Recovery: Analysis of Operating Parameters. International Journal of Mechanical Engineering and Technology, 9 (11), 1952-1961.

17. Alvarado V., Manrique E. (2010) Enhanced Oil Recovery: an Update Review. Energies, 3 (9), 1529-1575. https://doi.org/10.3390/en3091529.

18. Aleksandrov A. N., Rogachev M. K. (2017) Determination of Temperature of Model Oil Solutions Saturation with Paraffin. Mezhdunarodnyi Nauchno-Issledovatel'skii Zhurnal = International Research Journal, (6), 103-108 (in Russian).

19. Struchkov I. A., Rogachev M. K. (2017) Risk of Wax Precipitation in Oil Well. Natural Resources Research, 26 (1), 67-73. https://doi.org/10.1007/s11053-016-9302-7.

20. Belsky A. A., Dobush V. S. (2017) Autonomous Electrical Heating Facility Supplied by Wind Turbine for Elimination of Oil Wellbore Paraffin Deposits. 2017 International Conference on Industrial Engineering, Applications and Manufacturing (ICIEAM), 1-4. https://doi.org/10. 1109/ICIEAM.2017.8076256.

Received: 27 November 2018 Accepted: 29 January 2019 Published online: 29 March 2019 